\title{
HIV infection in elderly (patients aged more than 65 years)
}

\author{
Farahnaz Almasi \\ From $16^{\text {th }}$ International Symposium on HIV and Emerging Infectious Diseases \\ Marseille, France. 24-26 March 2010
}

\section{Background}

After 1996 with HAART, not only HIV infected people live longer but also new HIV infection occurs in older people.

\section{Methods}

Retrospective observational study in HIV infected patients older than 65 years old in order to find special epidemiologic and clinical aspects of HIV infection in elderly.

\section{Results}

Among 1680 registered HIV infected patients, there are 61 HIV infected patients aged 65 or older (range $=65-84$ ) including 13 women (21\%) and 48 men (79\%). There are 29 homosexual-bisexual (47\%), 24 heterosexual (40\%), only one patient blood transfusion and 7 patients denied any risk factors (11\%). 23 patients (38\%) with AIDS defining condition $(C), 13$ patients (21\%) were symptomatic (B) and 25 patients (41\%) were asymptomatic (A). Mean CD4 Count before antiretroviral treatment was 231, ranged 9 to 493. There were 24 patients ( $40 \%)$ with CD4 count less than 200 and 7 patients (11\%) with CD4 count less than 100 cells $/ \mathrm{ml}$. Recent CD4 count ranged 10 to 1080 and (mean 478). CD4 increase $=247$ after antiretroviral treatment. Mean viral load before treatment was 230184 . There are 5 untreated patients $(8 \%)$. After treatment 8 patients have detectable viral load more than 500 copies $/ \mathrm{ml}$ including 2 untreated patients. It means 6 patients (10\%) suffered from confirmed virologic failure and 7 patients $(11 \%)$ present detectable viral load but less than 500 copies.

Correspondence: dr_farahnaz_almasi@yahoo.com

Paris 6 University, Paris, France

BioMed Central @ 2010 Almasi; licensee BioMed Central Ltd.

\section{Discussion}

$80 \%$ of HIV infected people older than 65 are men. Homosexual contact is the major risk factor in this group. In spite of $40 \%$ asymptomatic patients there are near $40 \%$ stage C. $40 \%$ of patients were coming with low CD4 count (less than 200). Mean CD4 count before treatment was 231 which is less than younger HIV infected patients, may be because of low CD4 count in older patients and/or late diagnosis of HIV infection in elderly. Virologic response is as well as younger patients even better.

Published: 11 May 2010

doi:10.1186/1742-4690-7-S1-P16

Cite this article as: Almasi: HIV infection in elderly (patients aged more than 65 years). Retrovirology 2010 7(Suppl 1):P16.
Submit your next manuscript to BioMed Central and take full advantage of:

- Convenient online submission

- Thorough peer review

- No space constraints or color figure charges

- Immediate publication on acceptance

- Inclusion in PubMed, CAS, Scopus and Google Scholar

- Research which is freely available for redistribution

Submit your manuscript at www.biomedcentral.com/submit
C Biomed Central 